\title{
Lygia Fagundes Telles e o Bildungsroman no Brasil
}

\author{
Lygia Fagundes Telles and the Bildungsroman in Brazil \\ Lygia Fagundes Telles y el Bildungsroman en Brasil
}

Pedro Dolabela Chagas*

\section{Resumo}

O aumento da presença e relevância do Bildungsroman no Brasil em finais dos anos 40 do século XX; o lugar de Lygia Fagundes Telles nesse processo. Indicação de características da versão do subgênero então predominante; para descrevê-las, dada a importância de Telles para a história do subgênero no Brasil, a sua obra é tomada como referência principal do artigo: assim como a narração da história do subgênero ilumina as especificidades da sua obra individual, propõe-se que a análise da sua obra ilumina a história do subgênero no país. A seção inicial oferece uma definição operatória do Bildungsroman, descrevendo as suas características e motivações principais desde a sua aparição na Europa em finais do século XVIII. Uma seção seguinte discute a sua presença na história do romance brasileiro antes do período analisado, com foco comparativo no "romance de 30". Duas seções seguintes caracterizam o Bildungsroman brasileiro dos anos 50 mediante comparações entre obras de Telles e de Clarice Lispector e Carlos Heitor Cony. Ao final, faz-se uma nota sobre a importância do subgênero para o romance brasileiro posterior.

Palavras-chave: romance de formação, história do romance brasileiro, Lygia Fagundes Telles.

\begin{abstract}
This article examines the increased presence and relevance of the Bildungsroman in late-1940s Brazil and the role of Lygia Fagundes Telles in that process. In order to describe some of the characteristics of the subgenre that prevailed during that period, and given the relevance of Telles's work in the history of the subgenre in Brazil, her work will be taken on as the article's main reference. Just as the narration of the subgenre's history illuminates the specificities of her individual work, the analysis of her work will be used to illuminate the history of the subgenre in Brazil. The initial section offers a working definition of the Bildungsroman, describing its main features and motivations since its appearance in $18^{\text {th }}$-century Europe. A following section discusses its presence in the history of the Brazilian novel before the late 1940s, with a comparative focus on the "romance de 30 " ("1930s novel"). The following two sections characterize the 1950s Brazilian Bildungsroman through comparisons between works by Telles, Clarice Lispector and Carlos Heitor Cony. At the end, the importance of the subgenre for the Brazilian novel is briefly discussed.
\end{abstract}

Keywords: Bildungsroman, history of the Brazilian novel, Lygia Fagundes Telles.

\begin{abstract}
Resumen
El artículo trata sobre el aumento de la presencia y relevancia del Bildungsroman en Brasil a fines de los años 40 del siglo XX y el lugar de Lygia Fagundes Telles en aquel proceso. Indicación de las características de la versión del subgénero entonces predominante, para describirlas y dada la importancia la obra de Telles para la historia del subgénero en Brasil, se la toma como término de referencia: así como la narración de la historia del subgénero ilumina las especificidades de la obra de la autora, se presupone que el análisis de su obra ilumine la historia del subgénero en el país. La sección inicial ofrece una definición operativa del Bildungsroman, describiendo sus características y motivaciones principales desde su aparición en Europa a fines del siglo XVIII. Una sección siguiente discute su presencia en la historia de la novela brasilera anterior al período analizado, con foco en la "novela de los treinta". Dos secciones siguientes caracterizan el Bildungsroman brasilero de los años 50 bajo comparaciones entre obras de Telles, Clarice Lispector y Carlos Heitor Cony. Al final, una nota breve discute la importancia del subgénero para la novela brasilera posterior.
\end{abstract}

Palabras clave: Bildungsroman, historia de la novela brasileira, Lygia Fagundes Telles.

\footnotetext{
* Doutor em literatura comparada e professor da Universidade Federal do Paraná (UFPR), Curitiba, PR, Brasil. (Dorcid.org/00000003-0336-489X. E-mail: dolabelachagas@gmail.com
} 
Numa pensão de freiras, Ana Clara, Lia e Lorena lidam, cada qual a seu modo, com um contexto político e social conturbado: greve na universidade, perseguição de colegas militantes pelo aparato de repressão do regime militar, refúgio no consumo de drogas... Ana Clara idealiza o casamento com um homem rico enquanto rememora abusos sofridos na infância e na adolescência, afundando-se no escapismo; Lia se engaja na resistência ao regime; Lorena, filha da burguesia rural, ouve música e lê poesia em seu quarto enquanto espera notícias do amante. Três jovens sofrem o mundo na passagem para a vida adulta; as três devem aprender com as suas experiências os seus modos pessoais de inserção no mundo. $O$ aprendizado vem da experiência e não do saber acumulado, transmitido entre as gerações: teria As meninas um elemento de Bildungsroman? Isso demarcaria uma diferença histórica, pois até ali, em 1973, o subgênero não fora muito presente na história do romance brasileiro. $O$ Ateneu seria talvez um exemplo, mas parece que, enquanto a representação da identidade nacional esteve em primeiro plano na nossa literatura, a formação individual pela experiência do "mundo da vida" não despontou como tema recorrente - até que, aos poucos, isso começou a mudar.

Em 1932, Menino de engenho narrava a infância do protagonista num ambiente singular, sugerido como metonímia de um quadro social mais amplo: na proposta de que aquele ambiente, em seu condicionamento sócio-histórico, teria implicações para a passagem do narrador à vida adulta, estava inscrita uma noção de "formação". Em 1943, Perto do coração selvagem trazia implicações semelhantes ao representar um quadro social diferente: o ambiente da família nuclear "pequeno-burguesa", típica da classe média em franca expansão no Brasil urbano. Então veio a aceleração: em 1954 apareceu Ciranda de pedra; em 1956, O encontro marcado; em 1958, O ventre. Até então Bildungsromane pontuais se insinuavam em meio à massa de publicações; de súbito, obras ambiciosas despontavam em nossa produção. Haveria elementos de Bildungsroman em Grande Sertão: Veredas. Também mais tarde em Quarup, um clássico exemplar do subgênero. Limite branco, de Caio Fernando Abreu, voltaria à ambientação e temática de Perto do coração selvagem. Elementos pontuais ainda em Avalovara... Nos vinte anos que se seguiram à publicação de Ciranda de pedra, a noção de "formação" se tornaria importante para o romance brasileiro: eis o fenômeno que este artigo quer descrever.

Na variação do Bildungsroman que então se fortaleceu no Brasil, Lygia Fagundes Telles teria destaque. A rigor, nenhum outro romancista do período se dedicou tanto ao subgênero, e é estratégico que este trabalho se concentre na sua obra ao discuti-lo. Nessa medida, o artigo versará tanto sobre a história do Bildungsroman no país quanto sobre a contribuição que Telles lhe deu, esperando que um ponto fortaleça o outro: que a narração da história do subgênero ilumine as especificidades de sua obra individual e que, por sua vez, a análise da obra de Telles ilumine as especificidades da versão do subgênero que se fortaleceu no país.

O artigo traz uma seção inicial que oferece uma definição operatória do romance de formação, descrevendo suas características e motivações principais desde sua aparição na Europa em finais do século XVIII: em meu entender, esse primeiro passo é necessário para a própria justificação do tratamento do corpus selecionado como pertencente àquele subgênero. Segue-se a essa seção uma discussão da sua presença na história do romance brasileiro até os anos 1950, com foco na comparação com o "romance intimista" da década de 1930. A análise da contribuição de Telles envolverá duas outras seções, respectivamente dedicadas a delinear a versão do Bildungsroman que ganharia força nos anos 50 - mediante uma comparação entre a sua obra e a de Clarice Lispector -, e as diferenças que essa versão, que nunca foi monolítica, chegou a manifestar - mediante uma comparação com Carlos Heitor Cony. Ao final, faço uma breve nota sobre a importância do subgênero para o romance brasileiro posterior.

\section{O Bildungsroman}

O que é um "romance de formação"? Não há definição consensual nem exemplares "puros" ou "perfeitos" do subgênero. Ainda assim, acredito ser possível ensaiar uma descrição aproximativa.

Penso inicialmente em obras que, à semelhança de Os anos de aprendizado de Wilhelm Meister, de Goethe, mostram as dificuldades de autoafirmação de protagonistas jovens 
lançados a uma realidade social em processo de transformação e para cujo enfrentamento o saber tradicional, transmitido entre as gerações, era de pouca valia. $O$ problema, para o personagem, é encontrar um modo de inserção socialmente sancionado que respeite o seu desejo de autonomia. Na ausência de qualquer equacionamento tradicionalizado para a conciliação daqueles dois imperativos, para se orientar no mundo o personagem deve se formar pela experiência direta do real; ao menos idealmente, esse aprendizado o orientaria na imaginação e construção de uma inserção que lhe respeitasse e dignificasse subjetivamente, permitindo que suas crenças, seus desejos e suas vocações não fossem abafadas pela adequação a normas e expectativas preexistentes. Tudo dando certo, o resultado do processo poderia confirmar a possibilidade otimista da sua inserção final - ou não...

Como é comum no gênero romanesco, o Bildungsroman evoca possibilidades de ação e pensamento já em processo de disseminação social, mas ainda obscurecidos por hábitos e rotinas cristalizados. Mais especificamente, seus enredos simulam conflitos entre certas formas de subjetividade, de um lado, e, de outro, grupos hegemônicos e seus padrões discursivos: não se trata (ou não apenas) de ensaiar os termos possíveis para uma negociação entre um e outro polo, mas de encenar um quadro em que a afirmação de um indivíduo já socializado impõe o seu confronto com normas e discursos de pretensão hegemônica. Desse conflito, pelo menos em sua versão inicial - otimista - o romance de formação encenava, numa narrativa do desenvolvimento da personalidade, o movimento "da pura sujeição à auto-regulação" do sujeito, operado mediante um "processo de incorporação pelo qual o indivíduo é constituído e regulado como uma criatura [...] emancipada" (Slaughter, 2007, p. 9-10, tradução nossa). Tratava-se, pois, de uma "formação" para a ação intramundana e não para o recolhimento no "eu": o embate "eu-mundo" construía "o indivíduo como uma criatura social e o processo de individuação como um processo incorporador de socialização, sem o qual o próprio individualismo [implicado nas motivações do protagonista] perderia sentido" (Slaughter, 2007, p. 19, tradução nossa). Não por acaso, é comum que o narrador seja um adulto que recorda o seu tempo de juventude, resgatando os termos de equacionamento do seu (bem-sucedido ou fracassado) processo de aprendizado.

Moretti (1996) indica que, em seu momento inaugural na virada do século XVIII para o XIX, o gênero tendia a prometer felicidade futura, mas já na geração de Stendhal e Flaubert, e mais claramente no começo do século XX (em O jovem Törless, Os Buddenbrooks, Retrato do artista quando jovem), o confronto com as "leis do mundo" pelo jovem herói redundaria em pessimismo e frustração. Esse tom negativo nunca foi gratuito: ele evocava padrões de experiência determinadas por elementos coercitivos da estruturação social cuja superação se mostrava impossível, ou ao menos improvável. Desse modo, mesmo que o protagonista desse Bildungsroman pessimista fosse em parte inadaptado pela sua própria incoerência e autocontradição, ele não era "nem o indivíduo atomístico da filosofia libertária nem apenas o produto do determinismo social" (Slaughter, 2007, p. 20, tradução nossa). Ele nem era singular a ponto de a sua experiência não comportar comparação com outras experiências historicamente sincrônicas, nem genérico a ponto de ela ser integralmente explicável pela atuação de forças sociais externas: ele era altamente individualizado $e$ socialmente tipificado, e por isso o seu sofrimento, conquanto subjetivado, era representativo de um estado de coisas abrangente. Nesse sentido, em que pese a diferença entre a condição social de homens e mulheres - voltarei a isso adiante -, esse era um tipo de generalização que não obedecia a distinções de gênero. Friso esse ponto porque, ao tomar Lygia Fagundes Telles como referência, este artigo se distancia da perspectiva (a esta altura influente) de Cristina Ferreira Pinto, que situava na inadaptação final da personagem uma marca distintiva da versão feminina do subgênero:

O "Bildungsroman" feminino é uma forma de realizar essa dupla revisão literária e histórica, pois utiliza um gênero tradicionalmente masculino para registrar uma determinada perspectiva, normalmente não levada em consideração, da realidade. Ao nível do gênero, o "romance de aprendizagem" feminino distancia-se do modelo masculino principalmente quanto ao desfecho da narrativa. Enquanto em "Bildungsroman" masculinos - mesmo em exemplos modernos - o protagonista alcança integração social e um certo nível de coerência, o final da narrativa feminina resulta 
sempre ou no fracasso ou, quando muito, em um sentido de coerência pessoal que se torna possível somente com a não integração da personagem no grupo social (Pinto, 1990, p. 27).

Não: essa mesma inadaptação - dificuldades de integração social e baixo nível de coerência, para seguir o vocabulário da citação - acontecia em $O$ vermelho e o negro, A educação sentimental, $O$ jovem Törless, Os Buddenbrooks, Retrato do artista quando jovem. Não há nada de especificamente feminino no fenômeno, o que realça a importância de Telles, cujo lugar na história do romance brasileiro transcendeu as marcações de gênero. Tipicamente, no enredo do Bildungsroman o protagonista é inicialmente ingênuo, mas aberto à sensibilização pelo ambiente; ele é pouco autoconhecedor, mas está ansioso para identificar a sua vocação a contrapelo dos limites colocados pela ordem social, descobrindo por si mesmo a sua via própria de afirmação (existencial, material, política) a média distância das normas, expectativas e modelos legados pela tradição. Slaughter (2007, p. 20, tradução nossa) observa que a sua personalidade costuma ser pressuposta como "uma característica inata do ser humano que busca a sua mais livre e plena forma de expressão na condição pública, na figura do 'ser humano social'", mas com a crise colocada pela dificuldade de afirmação em seu contexto de vida o protagonista se torna inquieto, disposto a transitar entre lugares e pessoas e enfrentar o desconhecido, apreendendo da experiência as condições pessoais para uma acomodação possível. Mesmo em suas versões mais pessimistas, o Bildungsroman projeta, como utopia inicial, a acomodação entre o sujeito e a objetividade do grupo, entre a sua singularidade e as demandas de conformidade da coletividade.

Visto dessa forma, o drama individual pode receber uma conotação política universalista como o jogo entre o desejo de autonomia individual e a coação pela ordem. Se pensarmos uma definição de política que extrapole o quadro institucional, partidário e ideológico para incluir a micropolítica das relações pessoais (envolvendo, no século XX, as relações de gênero e de raça), e se pensarmos o desenvolvimento da personalidade de um indivíduo socialmente inserido como "um processo de [...] filiação em práticas e regras sociais, tradições constitucionais e hábitos institucionais, que agregam os indivíduos para formar uma comunidade política funcional" (Slaughter, 2007, p. 20, tradução nossa), o protagonista do Bildungsroman, por seu turno, estará claramente desviante em relação aos modos regulares do mundo - ele vive sob tensão.

Daí seu impulso para transitar entre lugares e pessoas como meio de autoconhecimento. Daí sua constante observação das lacunas entre as leis sociais - não escritas - e as volições, ideações e padrões de moralidade que ele mesmo projeta como condições para sua própria autoafirmação e, não raro, para a realização da justiça: a lacuna entre o real e o ideal, entre os desejos de afirmação pessoal e as condições limitadas de afirmação contextualmente oferecidas, revelam tanto sobre a sua psicologia quanto sobre a sociedade em que ele vive. Tudo dando certo, a "formação" levaria a uma conciliação entre "leis objetivas" e "leis subjetivas", mas a antevisão dessa possibilidade oferece um modelo de enredo igualmente adequado para a encenação do seu fracasso, ou mesmo da sua virtual impossibilidade - pela impossibilidade de induzir da experiência do mundo um modelo de ação moralmente satisfatório e pragmaticamente efetivo nas condições presentes.

O Bildungsroman afirmativo narrava a história de um protagonista afinal integrado à sociedade, "compartilhando a vontade geral sem o recurso à coerção social" (Slaughter, 2007, p. 26, tradução nossa). Em sua versão pessimista, ele se tornaria particularmente adequado à representação das condições de vida de grupos politicamente minoritários, como as jovens mulheres de Lygia Fagundes Telles e o jovem homossexual de Caio Fernando Abreu. Em ambas as versões, a expectativa político-normativa da igualdade era reafirmada para que fossem dramatizadas as dificuldades práticas da sua afirmação, dentro de contextos em que, pelo menos marginalmente, aumentava a demanda por ela: "a proeminência histórica do gênero corresponde a períodos de crise social sobre os termos e mecânicas da emancipação política, sobre o significado e o escopo da cidadania, ou seja, sobre o processo de incorporação" (Slaughter, 2007, p. 27, tradução nossa).

Se o Bildungsroman dramatiza a fraqueza do saber tradicional na orientação das escolhas individuais numa realidade instável, o protagonista deve ser tanto um agente transformador de sua própria condição, quanto um observador atento das falas e ações de outros personagens. Ele tende a 
imergir num dialogismo intenso: em seu processo de formação, o processamento dos discursos sobre o real é tão importante quanto a experiência direta do real; à medida que experiências são confrontadas com juízos, pensamento e crenças, ele amadurece moral e cognitivamente.

Em que medida essas características estariam presentes em Lygia Fagundes Telles e seus companheiros de geração?

\section{O Bildungsroman no Brasil}

Em 1974, Massaud Moisés comentava que, de autoria brasileira, "pode-se considerar romances de formação, até certo ponto, [...] O Ateneu (1888), de Raul Pompéia, Amar, verbo intransitivo (1927), de Mário de Andrade, os romances do 'ciclo do açúcar' (1933-1937), de José Lins do Rego, Mundos mortos (1937), de Octávio de Faria [...]" (Moisés, 2004, p. 56). Um total de quatro autores e oito obras que seriam romances de formação "até certo ponto": descontado o fato de que - dada a inexistência de qualquer "exemplar perfeito" do subgênero para além do próprio Wilhelm Meister, a partir do qual a descrição foi criada - qualquer obra será um romance de formação apenas "até certo ponto", tendo em vista que o subgênero, até então, fora incomum no Brasil.

Nos cinco romances do ciclo de José Lins do Rego - Menino de engenho, Doidinho, Banguê, Moleque Ricardo e Usina - há duas trajetórias formativas distintas: as de Ricardo e Carlos de Melo. Carlos é o narrador dos três primeiros volumes, que rememoram a sua infância no engenho do avô. O primeiro se dedica à sua chegada e integração inicial ao lugar; nos seguintes, ele vai para um colégio, começa a adquirir consciência de sua posição no mundo, forma-se em advocacia e volta a viver com o avô doente no engenho, agora decadente. Ricardo, por sua vez, é um garoto pobre do engenho que foge para a cidade e vive como operário antes de ser preso durante uma greve e decidir voltar ao engenho, agora com outro dono. São duas estórias de formação num período de transformação social (o processo de modernização econômica que levaria ao privilégio da indústria sobre a agricultura tradicional): Carlos é um membro da elite que herda as propriedades do avô e se forma advogado; Ricardo é vítima da desigualdade social, e sua formação o leva à conscientização política. Ambos os "ciclos" focam o juízo na crítica dos ambientes sociais representados; nessa medida, a narração do processo da Bildung pretende fornecer um ângulo adequado para a crítica social.

Mundos mortos também integra um ciclo, o da "tragédia burguesa", concluído apenas em 1979 (num total de treze volumes). Nos dois primeiros, Mundos mortos (1937) e Os caminhos da vida (1939), acompanhamos os dilemas morais de estudantes de um colégio católico. Ivo é cindido entre a norma moral da Igreja e os impulsos sexuais que ele começa a sentir; Roberto rompe com aquelas normas ao assumir a sua atração sexual por um colega; Branco, em direção contrária, se isola dos colegas ao reafirmar a sua fé. Enquanto isso, o padre Luís sofre ao observar a aparente incompatibilidade entre a realização da felicidade individual dos seus alunos e a obediência à norma moral: assim formatado como uma escolha entre alternativas contrapostas, o equacionamento do conflito se torna improvável; ou bem o jovem acata a norma, ou ele se entrega à culpa e ao sofrimento. Tal como nos "romances sociais" do período, o conflito é enquadrado por critérios externos ao "eu", pelos quais as escolhas do "eu" serão objetivamente julgadas - o contrário da Bildung romântica, portanto, com a sua afirmação da autonomia moral do "eu" diante do "mundo da vida".

Este é o ponto central: se o juízo das ações e modos de vida é decidido por um padrão externo ao "eu" (e aparentemente inflexível à variação individual), não é dado ao protagonista o poder de desenvolver um modo próprio de relacionamento moral com o mundo. Não é que em José Lins do Rego e Octavio de Faria o juízo moral estivesse desprovido de complexidade: pelo contrário, em suas obras toda asserção é tensionada pela ausência de sugestões de vias conciliatórias que pareçam claramente eficientes; ao final, os problemas não são solucionados e as tensões seguem pulsando. $\mathrm{O}$ que eu quero destacar é que os termos sugestionados como adequados para o juízo não vinham dos personagens, mas da voz narrativa, impedindo que um princípio de plena autonomia individual emergisse como valor dominante naqueles mundos ficcionais. Aquelas obras eram Bildungsromane, sim - mas "até certo ponto". 
Isso permite precisar a diferença dos anos 1950 num Brasil em que a família, a religião, o ethos profissional pareciam ter perdido autoridade para suprir suas potenciais funções formativas. Diminuía a estabilidade da ordenação social, condição para a legitimação do saber tradicional, o que por sua vez legitimava a interpretação pessoal do real - especialmente no anonimato das metrópoles -, sob a mediação de discursos que aceleravam a mudança dos hábitos e do pensamento: a filosofia existencialista, a esquerda revolucionária, a crítica dos gradientes de poder entre as gerações, o quadro simbólico transformado pelo rádio e pelo cinema... A classe média crescia em sua instabilidade constitutiva: se o Bildungsroman até então não fora importante na história do romance brasileiro, uma das razões pode ter sido a facilidade com que, tradicionalmente, indivíduos de estratos sociais medianos (a típica inscrição do Bildungsroman) conseguiam se inserir numa sociedade pouquíssimo competitiva (pela exclusão de largos estratos da população e pela alocação consuetudinária dos jovens de elite em posições sociais previstas). A modernização (e a crítica da modernização) econômica desestabilizaria esse quadro, valendo notar o elemento qualitativo dessa mudança: em Memórias de um sargento de milícias (1854), a "formação" pressupunha uma sociedade estável, cabendo ao herói aprender um modo seguro para a sua inserção definitiva (a "autonomia romântica" não era questão); em Memórias póstumas de Brás Cubas (1881) e O Ateneu (1888) a sociedade ainda parecia estável, mas já se notava nos protagonistas certa falta existencial; nos anos 1950 a "existência" viria ao primeiro plano, impondo ao protagonista o imperativo de formular uma relação com o real que lhe permitisse afirmar a própria autonomia - o "pequeno mundo" do seu estrato social mediano passara a parecer uma prisão.

Por exemplo, em Ciranda de pedra, Virgínia seria marcada desde a infância pela instabilidade familiar - a separação dos pais (algo raro, então), os problemas psiquiátricos da mãe, a relação conturbada com as irmãs, até a descoberta, no começo da vida adulta, de que aquele não era o seu pai verdadeiro. Alienada em casa, ela tenta se inserir sem sucesso num grupo de relacionamento pessoal; após o retiro num internato, ela entende que só encontraria equilíbrio longe dali, e parte em viagem. Ao final do enredo, a percepção desse amadurecimento se dá no contato com as coisas da infância, encerrando o seu longo processo de transformação; passeando pela chácara onde passara os primeiros anos de vida, ela tem um momento de epifania:

Retirando a mão da água, mergulhou-a na relva. Não, não, tudo aquilo era memória, chegara a hora de dizer-lhe adeus. O fluxo da vida que corria como aquele rio era tão belo, tão forte! O sonho era o futuro. Tinha apenas que libertar-se e viver. Agora os passarinhos conversavam em segredo enquanto se aninhavam em meio do arvoredo. Lembrou-se da Irmã Mônica a lhe perguntar se era feliz. "Sinto uma grande tranquilidade", respondera. E consigo mesma, "Uma indiferença, desde que tranquilidade e indiferença, no fundo, significam a mesma coisa". Só agora via o quanto se enganara. Indiferença era a paz estagnada de Otávia. E tranquilidade era aquilo, aquela quietude sob a qual a vida palpitava (Telles, 1984, p. 199-200).

Quão contemporâneo isso soava em 1954? Ao rejeitar a "paz estagnada" de Otávia, Virgínia entendia que a sua inadaptação derivava da maior complexidade de sua personalidade: ela não se desviava das expectativas sociais gratuitamente, mas em obediência à necessidade de construir, de maneira exploratória e autorreflexiva, uma identidade pessoal ainda em devir. Essa lentidão faria com que ela só viesse a compreender o seu próprio passado ao final do processo que lhe reabriria o futuro: entre o seu "eu" passado que ela a muito custo viera a compreender, e o seu "eu" futuro que ela somente viria a conhecer após o final da narrativa, ela abandonava o longo presente em que vivera estagnada e atormentada, para comprimir o presente ante a viagem que anunciava a sua libertação.

Assim seria o Bildungsroman brasileiro dos anos 1950: melancólico, doloroso, inacabado - e apenas ocasionalmente otimista. O pessimismo quanto à futura inserção feliz do protagonista em seu mundo iria predominar; num momento em que o existencialismo filosófico ganhava força e padrões morais tradicionais passavam a ser criticados, mas não transformados, não surpreende que desfechos negativos adquirissem maior verossimilhança. Assim seria $O$ encontro marcado (1956), onde a trajetória de Eduardo é cheia de perdas e desencontros: um amigo se suicida, o pai morre distante, um filho é perdido no ventre da esposa, os amigos se 
afastam, culminando no seu retorno melancólico à cidade natal, que ele não mais reconhecia: "Encontrou a cidade diferente, mudada. Agitação pelas ruas, prédios novos, gente andando para lá e para cá, como se realmente tivesse urgência de ir a qualquer parte. Os elevadores funcionavam todo o tempo" (Sabino, 2013, p. 288). Na narração pelo herói já amadurecido, a identidade do protagonista vai sendo construída por sua ironia e autodistanciamento em relação às identidades que ele mesmo ia forjando para si ao longo da vida - como quando ele, um adolescente que há pouco se definira como "poeta maldito", se autocongratula pelo dinheiro recebido com a publicação da sua literatura:

Ao fim de quinze dias de vagabundagem, o dinheiro acabou. Saiu pela rua, mão no bolso, sentindo que naquele momento começava a viver. Pobreza, fome, miséria - tudo era preciso, para tornar-se escritor. Escrevera um conto em que dizia isso, mandara para um concurso de contos. No Largo do Machado pediu para ver um exemplar da revista pronto, lá estava seu conto premiado no concurso. Cem mil réis. Compareça à redação para receber... Compareceria imediatamente. E a pobreza, a fome? Na vida tudo seria assim, a solução se apresentando imediatamente, mal começasse a buscá-la, gozando ainda as dificuldades do problema? Na vida tudo lhe seria assim (Sabino, 2013, p. 32).

Não há sinal de alegria ou confiança no futuro: se o personagem não acredita em si mesmo, menos ainda ele acreditará nos modos de afirmação social que lhe aparecem. De maneira semelhante, em $O$ ventre (1958) o narrador de Cony é um filho bastardo que narra a sua vida da infância ao suicídio do irmão, envolvendo a atração que desde a adolescência ele sentia pela cunhada. Tudo é narrado com dureza, descrença, com uma ironia que beira o niilismo, negando à vida qualquer valor univocamente positivo. O suicídio é uma ideia fixa, cuja realização futura é ironicamente colocada como meio potencial de afirmação do autocontrole:

Esperássemos um pouco. Veríamos o que a vida ia fazer comigo. Era gostoso adiar a própria morte, ter o poder de continuar vivendo - a menos que um teto caísse sobre a cabeça, um carro me atropelasse, um ataque do coração me fulminasse. A questão, como sempre, era o controle, saber até onde podia ir, sem esperar pela decomposição aos pedaços, os espasmos cerebrais, a uretra obstruída, o câncer no duodeno (Cony, 1998, p. 180).

Nas três obras comentadas predomina o tom melancólico pela falta de sentido da vida normalizada, a observação e reflexão distanciada de detalhes mesquinhos do cotidiano, o forte individualismo do sujeito solitário em seu desvio das expectativas do mundo presente, um quadro de relações familiares complicadas em meio ao distanciamento de problemas políticos e sociais urgentes: assim era o novo Bildungsroman brasileiro. $\mathrm{O}$ marco inicial fora lançado por Clarice Lispector em Perto do coração selvagem, que afinal seria o seu único romance de formação; nas décadas seguintes, Lygia Fagundes Telles se tornaria a sua maior praticante no Brasil: tomemo-las como guias para observar a afirmação do subgênero.

\section{Qual Bildungsroman?}

Em Perto do coração selvagem (1943) e Ciranda de pedra (1954), o ambiente familiar codetermina a formação inicial da personalidade da protagonista feminina. $\mathrm{O}$ ambiente doméstico determina suas ações e seu sofrimento; em particular, a família pequeno-burguesa não compreende nem sabe lidar com a singularidade daquelas personagens. A tia de Joana estranha o seu comportamento: "Como um pequeno demônio... Eu, com minha idade e minha experiência, depois de ter criado uma filha já casada, fico fria ao lado de Joana..." (Lispector, 1998, p. 50). Virgínia também parecia estranha, o que as freiras do colégio explicavam pelo seu histórico familiar: "'Parece tão dissimulada', dizia Irmã Clara. 'Tem olhos de quem já viu coisas terríveis!' - assombrava-se Irmã Flora. 'E é filha de pais separados, houve muito escândalo' - pensavam todas" (Telles, 1984, p. 104). A contrapelo dessas opiniões, a narração sugere que tal estranheza não é apenas explicada, mas acima de tudo justificada no contexto familiar: se nem Joana nem Virgínia haviam crescido num ambiente doméstico convencional, ou especialmente em ambientes que soubessem compreendê-las e incorporá-las, a estranheza era uma resposta adequada às suas condições de relacionamento doméstico. 
Nesses termos, se - como vimos - não se justifica a descrição da condição do protagonista masculino do Bildungsroman como um herói que "passa por processo durante o qual se educa, descobre uma vocação e uma filosofia de vida e as realiza" (Pinto, 1990, p. 13), e estando desacreditada a polarização entre o suposto predomínio do otimismo nas versões masculinas e do pessimismo nas versões femininas do subgênero, isso não elimina que Cristina Ferreira Pinto estivesse certa ao postular que "Segundo as expectativas que a sociedade tinha em relação à mulher, [...] seu 'aprendizado' se daria dentro de um espaço bem delimitado" (Pinto, 1990, p. 13), um espaço que estaria inscrito, acima de tudo, na intimidade da casa da família. No entanto, a mesma Cristina Ferreira Pinto seria capaz de afirmar, na sequência do argumento, que a partir "[d]os limites do lar e da família [não havia] margem para o seu crescimento interior" (Pinto, 1990, p. 13, grifo nosso). "Falta de crescimento interior" nas personagens de Telles e Lispector? No meu entender, nada está mais distante do que a leitura das obras indica: exatamente o contrário acontece, ainda que de maneira conflitiva e, ao final, não necessariamente feliz.

A memória é decisiva para a caracterização das protagonistas, talvez ainda mais em Telles do que em Lispector - que confere maior peso à condição inata (psicológica, "espiritual”) da singularidade da personalidade, enquanto Telles a explica, em grande parte, pela influência do ambiente. Em ambos os casos o resultado é a solidão. Em Lispector o isolamento é uma condição para o aprendizado: ele tanto é imposto à personagem, quanto é um modo positivo de expressão e contato com o mundo, tornando-se, com o tempo, uma condição para o autofortalecimento. Em Telles a situação é outra: o isolamento é, sim, imposto a uma personagem que, no entanto, vai senti-lo como condição a ser superada. Em Lispector a solidão é assumida como modo de autoafirmação e eventual libertação; em Telles a afirmação prevê, ao menos em seu momento inicial, o pertencimento coletivo como ideal pessoal, possibilidade cuja realização, em Lispector, é cedo descartada. Em ambas as obras o isolamento traz sofrimento e amadurecimento contra o risco da estagnação, da sujeição, do vazio - mas a Joana de Lispector parece mais segura em seu espaço marginal, enquanto as heroínas de Telles, nalguma medida e por um longo tempo, sentem a própria inadaptação como falha pessoal.

Quando Joana finalmente ascende ao autoconhecimento, tal como em outras personagens de Lispector, isso terá decorrido de um engajamento ativo no mundo: ela não é vítima passiva do contexto em que vive. Em Telles, por sua vez, a maior expectativa de pertencimento faz com que a personagem se lance voluntariamente em um jogo social que ela não domina, o que termina por relegá-la, em certos contextos, a uma posição passiva - é um jogo cujas regras a personagem não entende bem, e no qual ela decididamente não se sente à vontade: "Riram-se as duas e Virgínia acompanhou-as com um sorriso. Era essa a espécie de conversa que temia e ao mesmo tempo desejava. Por que Afonso nunca se lembrara de convidá-la? Por quê? [...] Sentiu-se abandonada, largada lá atrás" (Telles, 1984, p. 49). Segue-se a esta cena um diálogo entre as irmãs em que Virgínia permanece como mera expectadora; ao final, o seu sentimento não poderia ser outro: "E como se obedecessem ao mesmo sinal, [as irmãs] desataram a rir. Virgínia esboçou um sorriso. A verdade é que quando as duas se uniam, ela teria mesmo que ficar de fora" (Telles, 1984, p. 50).

Virgínia é afetada diariamente por esse tipo de situação, em que ela sofre com ações que não lhe são dirigidas por sentir-se excluída da comunicação. Por muito tempo ela será dominada pelo contexto, sem muito poder de escolha; boa parte do seu processo formativo se dará nessa experiência de impotência, fragilidade, exclusão. Em parte o problema é epistêmico. Um importante gradiente de saber é imbricado na trama: Virgínia é mantida em ignorância por todos ao redor; ela é a última a saber o que acontece na família, o que reduz o seu poder e importância; quando ela finalmente toma conhecimento dos segredos, ela assume a iniciativa do jogo. Em Lispector, por outro lado, ignorantes são as pessoas ao redor da protagonista, "prisioneiras da caverna" que não veem muito longe; com isso, o aumento progressivo do saber da protagonista é o aumento progressivo do seu autoconhecimento, que lhe permite cada vez mais identificar a pobreza do conhecimento alheio.

Para as personagens de ambas as autoras o presente é insatisfatório, insuficiente - problemas no modelo familiar, falta de liberdade e de sentido da vida, a mistura desses fatores. Mas elas sugerem soluções diferentes: por muito tempo as protagonistas de Telles se apegam a um passado 
saudoso ou imaginado, quando a vida poderia ter seguido outra direção; a Joana de Lispector, por sua vez, é mais precoce ao se lançar ao futuro e procurar alternativas no desconhecido; em ambas as trajetórias, o ponto de culminância está no desprendimento do passado e no reinício da vida. Em ambas permanece certo otimismo de fundo que, na obra de Telles, estaria visível em Ciranda de pedra, se tornaria remoto em Verão no aquário, e quase desapareceria em As meninas.

Sobre a ironia e a seriedade, por fim. Em Telles, o cinismo da heroína revela a sua imaturidade: Lorena, Raíza e Virgínia às vezes não parecem levar muita coisa a sério, inclusive os seus próprios valores, opiniões e comportamentos. Tudo lhes parece pequeno demais: "Você faz ironia, Raíza. Essa a principal diferença entre a sua mãe e você. Patrícia atingiu a profundidade, lá onde a ironia não chega jamais, como escreveu Rilke" (Telles, 1981, p. 77). Isso indica que a passagem à maturidade implicará uma passagem à seriedade e, acima de tudo, à responsabilidade. Também para a protagonista de Lispector a formação, na medida em que culmina na tomada de consciência, pressupõe sobriedade, racionalização, distanciamento na observação do mundo imediato; a diferença, mais uma vez, é que nela a seriedade está presente desde o início, ainda que lançada num quadro afetivo conturbado:

Porque ninguém mais na sua vida, ninguém mais talvez haveria de lhe dizer, como o professor: vive-se e morre-se. Todos esqueciam, todos só sabiam brincar. Olhou-os. Sua tia brincava com uma casa, uma cozinheira, um marido, uma filha casada, visitas, o tio brincava com o trabalho, com uma fazenda, com jogo de xadrez, com jornais. Joana procurou analisá-los, sentindo que assim os destruiria (Lispector, 1998, p. 62).

\section{Companheiros de geração: Carlos Heitor Cony e Lygia Fagundes Telles}

Da comparação entre Telles e Lispector emerge a imagem de um Bildungsroman intimista, apenas timidamente otimista, e que pouco trazia ao primeiro plano a representação das transformações sociais cujas implicações sobre o quadro mental contemporâneo eram, afinal, vividas pelas personagens - ao contrário do que ocorreria em Quarup (1967), as mudanças políticas e sociais responsáveis pelas mudanças nas mentes e condições de vida não eram tematizadas no enredo. Para entender as possibilidades que o subgênero exploraria dentro dessa versão, passamos aos anos 1950: a comparação agora é entre Telles e Carlos Heitor Cony.

Também em Cony o indivíduo é tolhido pelos padrões hegemônicos de pensamento e ação. Logo de saída, porém, o narrador de $O$ ventre é incisivo em seus juízos sobre quem ele é e qual é o seu lugar no mundo - enquanto Telles, como vimos, investe tempo narrando o processo que levaria àquela maturidade. Mais uma vez, a comparação revela o menor componente de inatismo na caracterização das protagonistas de Telles, cujas personalidades se cristalizam apenas mediante a vivência prolongada do mundo.

Essas diferenças entre os tipos de protagonista ficam claras na comparação entre Antes, o verão (1964) e Verão no aquário (1963). Quando o casamento do Luís de Cony entra em crise, ele se questiona sobre o papel de pai e marido que assumira ao longo da vida, e então se percebe que ele se compreendia como um homem plenamente livre que a certa altura optara por aquela posição, acreditando preservar a todo instante a opção de mudá-la (o que ocorre ao final do enredo, com a separação do casal). Ou seja, ele pressupõe que a sua liberdade está continuamente preservada: o seu autoconhecimento está dado e a sua autorreflexão é constante, em seu embate com as expectativas medianas contra as quais ele afirma a sua autonomia. $\mathrm{O}$ mesmo ocorre em $\mathrm{O}$ ventre, em que o narrador rememora o passado armado de uma noção amadurecida de seu processo de formação já transcorrido: o vazio e a violência velada de suas primeiras experiências cedo o levaram a uma descrença racionalizada nas leis do mundo, que logo the indicara as condições pessoais para uma autonomização que estaria implicada até mesmo nos momentos em que ele agia contra suas próprias convicções (por comodismo, covardia, cinismo...).

Em Verão no aquário a tensão é outra. Tal como outras heroínas dos Bildungsromane de Telles, Raíza inicialmente busca inserir-se na coletividade (no círculo social de Marfa, no afeto da mãe), e o enredo então dramatiza o seu processo de autoconhecimento: apenas em seu ponto de chegada ela reinterpretaria a sua dificuldade de inserção como um índice de autovalorização. Aí 
ela ascende ao tipo de questionamento ao mesmo tempo social e existencial do qual os personagens de Cony partem desde o início, como ocorre ao final deste trecho:

Vou fazer uma visita a tio Samuel - não foi o que eu disse a Marfa? A minha mãe? Marfa ficou indiferente e minha mãe duvidou. Mas por que tinha que duvidar? Por que tem que achar que só penso em sexo? Acenei para outro carro. Ela duvidara e isso atingia fundo quem representava o tempo todo como eu, Marfa estava certa, eu só agia em função das pessoas em redor. Caso contrário, que importância tinha que acreditassem ou não em mim? Se não mentia, se realizava o que me propusera, desde as coisas mais insignificantes até as mais decisivas - que importância tinha se viesse o aplauso ou a vaia? (Telles, 1981, p. 103).

O seu pensamento muda nesse processo: se no início Raíza se resumia a justificar e explicar os seus sentimentos - processo que a dominava, pois de tanto tentar defini-los ela acabava por deformá-los e ver-se definida por essas deformações -, ao final ela estará mais autônoma em relação ao mundo e às suas próprias emoções. Em suma, Telles tende a narrar a lenta passagem à autonomia, enquanto os personagens de Cony desde cedo afirmam a própria liberdade ao se distanciarem afetivamente da coletividade. Certamente há menos esperança em Cony, que apresenta reflexões existenciais de personagens armados de concepções sobre a vida prática que os colocam no limiar do niilismo - em Telles, alguma promessa de felicidade permanece pairando como possibilidade.

Em comum, em ambos os autores os personagens se valem do autoconhecimento para estabelecer a diretriz moral que seguirão na vida coletiva, liberdade que afinal lhes permitirá, sob o apelo do momento, adotar diferentes posturas sem perder a integridade. É curioso que, nesse processo de afirmação moral, as personagens de Telles em certa medida se orientem pela norma tradicional: especialmente em Ciranda de pedra e As meninas o consumo de drogas e a licenciosidade sexual, por exemplo, recebem um juízo negativo, enquanto a fidelidade e o compromisso amoroso e familiar são objetos de elogio. Não predomina em suas obras um viés moral transgressor ou iconoclasta - a Raíza de Verão no aquário, por exemplo, vê no religioso André um modelo de liberdade e autenticidade.

Da mesma maneira, em certa medida Virgínia se sente deslocada em seu grupo social em decorrência de suas normas morais, consideradas ingênuas por muita gente ao seu redor, o que leva à projeção de um contraste, no plano na narração, entre o seu desejo de estabilidade e solidez nas suas relações pessoais e a frivolidade do seu meio. Isso aumenta seu isolamento, o que ao final a motivaria, ao decidir viajar para a Europa, a assumir a sua responsabilidade pelas próprias crenças e ações, à revelia do juízo alheio. É o ponto ao qual Telles parece dirigir a sua narrativa desde o início, configurado em seu desfecho veladamente otimista:

"Para isso ele nos deu pernas". Mas seria este realmente um plano de fuga? E os anos todos que vivera percorrendo, de norte a sul, o mundo que criara dentro de si?! E aqueles longos anos de desvairados sonhos não seriam as fugas verdadeiras, com os pés ancorados? "E mesmo que seja esta uma fuga", admitiu com humildade. Podia ser a mais frágil das soluções, mas não lhe traria, pelo menos por ora, nenhum sofrimento. Já bebera muito da sua taça e, embora estivesse convencida de que ainda restava algo no fundo, uma voz lhe soprava que agora era a trégua.

Deixou cair os braços ao longo do corpo. A viagem marcaria a primeira etapa. E depois? (Telles, 1984, p. 190).

Enquanto isso, em Cony é sempre improvável que os protagonistas se apoiem na moral tradicional. Eles desde o início são autossuficientes, o que não lhes evita constante raiva ou sofrimento: para manter a própria integridade em meio à coletividade uma estratégia pode ser $\mathrm{o}$ fingimento, por meio do qual se consegue conviver com os demais sem abandonar intimamente as próprias conviç̧ões. Atitudes que parecem indicar passividade são, na verdade, uma estratégia de autopreservação, que permitem manter certo isolamento de segurança.

Interessa ainda mencionar que, por mais que em ambos os autores seja majoritária a presença de cenários urbanos, Cony tende a explorar ambientes abertos, enquanto Telles se concentra em cenários fechados. Em Telles, essa atmosfera reforça a força do grupo sobre as 
personagens principais, que se veem imersas em ambientes densos, claustrofóbicos, rodeadas pelos mesmos rostos e ideias com os quais elas não se comunicam muito bem. Em Cony, não é incomum que os indivíduos se vejam em deslocamento por espaços amplos, tornando-se o centro da cena e das próprias preocupações: o espaço favorece que eles apareçam como indivíduos e não partes de um grupo, como quando eles se veem soltos na multidão. Para ambos os autores os espaços são correlatos físicos e visuais dos conflitos encenados que, em Telles, se dão entre indivíduos desviantes e os grupos em que eles buscam se integrar - daí a preferência por situá-los em ambientes apertados, sufocantes, onde as pessoas se pressionam mutuamente -, e que, em Cony, envolvem indivíduos que não entram em conflito aberto com o grupo por saberem dele proteger-se com autoisolamento e flexibilidade de ação - daí a preferência por espaços amplos e pela liberdade de movimento.

Dessas leituras comparativas Telles emerge como uma construtora de enredos que preservam o ideal da inserção, enquanto Lispector e Cony narram crises que estão desde cedo determinadas pela autonomização radical do protagonista. Mas, de maneira geral, que presença esses e outros elementos mencionados do Bildungsroman brasileiro dos anos 1950 teriam no nosso romance posterior? Qual seria, em outras palavras, o legado histórico do subgênero?

\section{O Bildungsroman: seu lugar na história}

José Lins do Rego e Octavio de Faria escreviam para a esfera pública; Clarice Lispector, Lygia Fagundes Telles e Carlos Heitor Cony pareciam ignorá-la: a "sociedade brasileira" não fornecia o tema nem a plateia; apenas a nossa classe média e "burguesia" entravam no foco. O "povo" não aparecia, o que não implicava "alienação": o drama do indivíduo desviante era legitimado literariamente sem o imperativo do engajamento político. Talvez a urbanização, a expansão e enriquecimento da classe média, a mitigação da ênfase da nossa literatura na representação da identidade nacional (o Bildungsroman foi contemporâneo do concretismo, por exemplo), tenham aberto o campo para aquela versão intimista do romance de formação. Mas não quero me aventurar mais uma vez pela explicação histórica, terreno em que é enorme o risco da generalização. Mais interessante é sintetizar, à guisa de encerramento, a importância daquele Bildungsroman para a história do romance brasileiro, envolvendo a contribuição particular de Lygia Fagundes Telles.

Essa importância pode ser sumarizada numa frase: pela primeira vez na história do nosso romance o sujeito romântico, conforme delineado no primeiro romantismo alemão, se consolidava como personagem-tipo. Certamente não foi a sua primeira aparição no Brasil; elementos do "sistema-sujeito" - como o chamariam Philippe Lacoue-Labarthe e Jean-Luc Nancy - prenunciado em Schlegel e Novalis despontaram, de maneiras diferentes, em Machado de Assis, Oswald de Andrade, Cyro dos Anjos. Mas parece que apenas nos anos 1950, talvez pela influência do existencialismo - vide Lições de abismo (1950), de Gustavo Corção -, eles se tornariam comuns no nosso romance. Com isso, pela primeira vez encontramos séries de personagens cuja inadaptação ao mundo revelava a insuficiência do mundo, e não do personagem. Pela primeira vez esse mundo era objetivado como uma totalidade moral, e não social ou política, a ponto de permitir que sua crítica fosse concentrada na pequena burguesia, sem incluir necessariamente as camadas mais pobres da população (que não raro sequer apareciam no enredo). Pela primeira vez os valores criticados na sociedade atual não atentavam para a nossa construção nacional, em sua condição social e política, mas para problemas originalmente identificados na Europa oitocentista: a hipocrisia no contraste entre a aparência pública e a conduta privada, o hedonismo consumista, a rigidez nas relações pessoais, a crise de sentido. Pela primeira vez a autonomia individual era objeto de uma valoração incondicionalmente positiva, às vezes unilateralmente positiva - se em Telles e Cony pode-se dizer que os protagonistas eram falhos e equívocos em seus comportamentos, i.e. em seus exercícios da autonomia, em Lispector o isolamento do sujeito desviante comportava um elogio integral ao desvio, justificado numa crítica igualmente integral ao quadro social do qual ele se desviava. 
Em alguma medida, todos esses elementos foram trabalhados por Lygia Fagundes Telles nos quase vinte anos entre as publicações de Ciranda de pedra e As meninas. Não está claro se, a partir de então, o Bildungsroman tenha continuado a prosperar no Brasil, mas transparece que com ele o nosso romance ganhou temas, personagens e modelos de conflito que nunca mais sumiriam de nossa produção. Decerto não é preciso narrar um processo de "formação" para remeter a qualquer um dos elementos mencionados nesses últimos parágrafos, algo que a produção romanesca posterior tanto comprovaria. Em todo caso, foi em narrativas de formação que eles ganharam visibilidade e presença no romance brasileiro, numa contribuição histórica de Telles e seus companheiros de geração.

\section{Referências}

CONY, Carlos Heitor (1998). O ventre. 8. ed. São Paulo: Companhia das Letras.

LISPECTOR, Clarice (1998). Perto do coração selvagem. Rio de Janeiro: Rocco.

MOISÉS, Massaud (2004). Dicionário de termos literários. 12. ed. São Paulo: Cultrix.

MORETTI, Franco (1996). Modern epic. The World System from Goethe to García Marquez. New York: Verso.

PINTO, Cristina Ferreira (1990). O Bildungsroman feminino: quatro exemplos brasileiros. São Paulo: Perspectiva.

SABINO, Fernando (2013). O encontro marcado. 94. ed. São Paulo: Record.

SLAUGHTER, Joseph R. (2007). Human rights, Inc. New York: Fordham University Press.

TELLES, Lygia Fagundes (1981). Verão no aquário. 7. ed. Rio de Janeiro: Record.

TELLES, Lygia Fagundes (1984). Ciranda de pedra. 25. ed. Rio de Janeiro: Nova Fronteira. 